\title{
Imagiologically aggressive presentation of paediatric multiple sclerosis
}

\author{
Pedro Barradas (10, ${ }^{1}$ Ana Sofia Esteireiro (1) , ${ }^{2}$ Filipe Palavra, ${ }^{3,4}$ Silvia Carvalho ${ }^{1}$
}

${ }^{1}$ Medical Image Department, Neuroradiology Unit, Centro Hospitalar e Universitário de Coimbra, Coimbra, Portugal ${ }^{2}$ Paediatrics Department, Centro Hospitalar do Oeste, Unidade de Caldas da Rainha, Caldas da Rainha, Portugal

${ }^{3}$ Center for Child Development Neuropaediatrics Unit, Hospital Pediátrico, Centro Hospitalar e Universitario de Coimbra, Coimbra, Portugal

${ }^{4}$ Coimbra Institute for Clinical and Biomedical Research (iCBR), Faculty of Medicine, University of Coimbra, Coimbra, Portugal

\section{Correspondence to} Dr Ana Sofia Esteireiro; esteireira@gmail.com

Accepted 8 February 2020

A) Check for updates

(c) BMJ Publishing Group Limited 2020. No commercial re-use. See rights and permissions. Published by BMJ.

\footnotetext{
To cite: Barradas $P$, Esteireiro AS, Palavra F, et al. BMJ Case Rep 2020;13:e234148. doi:10.1136/bcr-2019234148
}

\section{DESCRIPTION}

Multiple sclerosis (MS) is an immune-mediated demyelinating disorder of the central nervous system (CNS), which despite mainly afflicting young adults, has been diagnosed in the paediatric population, with $2 \%-5 \%$ of all patients showing symptoms onset before 16 years of age. ${ }^{1-3}$ MRI is fundamental in the diagnosis of this disease.

A 14-year-old girl was brought to the emergency room because of pain in both thighs and diminished sensitivity in the right leg and foot, with 3 days of evolution. Neurological examination showed hypoactive patellar reflexes. She denied any other neurological symptoms. After admission, she also had lumbar pain irradiating to the right lower limb. MRI showed countless focal white matter lesions in various locations, several of them with gadolinium enhancement (figures 1-2).

Given their distribution, MS and cerebral autosomal dominant arteriopathy with subcortical infarcts and leukoencephalopathy were considered as possibilities. However, her improvement with corticosteroids and positive oligoclonal bands in cerebrospinal fluid helped to confirm the diagnosis of MS. Also, in the MRI performed, MS criteria for dissemination in space and time (according to the revised 2017 McDonald criteria for MS) were met. $^{2}$ She started treatment with intravenous natalizumab (being the serology for John Cunninghamvirus negative), so far with an excellent tolerability (she has already made 13 infusions and no new relapses were identified). In the last clinical evaluation, at month 12 of treatment, she scored 1.0

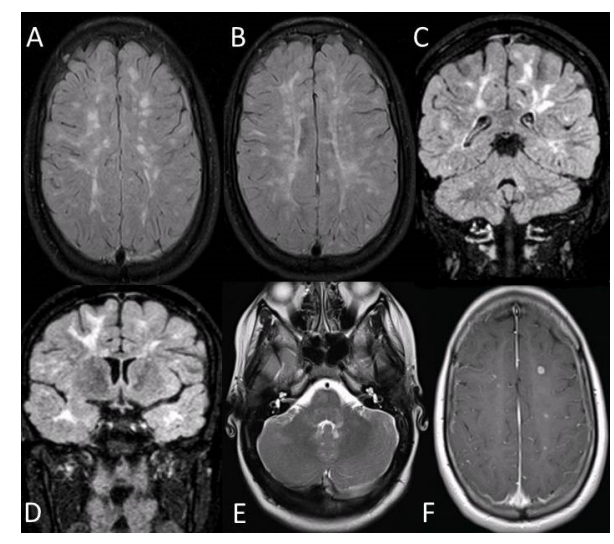

Figure 1 Axial $(A, B)$ and coronal $(C, D)$ FluidAttenuated Inversion Recovery (FLAIR) and axial T2 (E) images showing countless focal and confluent white matter lesions (juxtacortical, periventricular, subcortical, callosomarginal, capsular, pontine and cerebellar). Axial T1 image (F) after administration of gadolinium showing several active lesions.

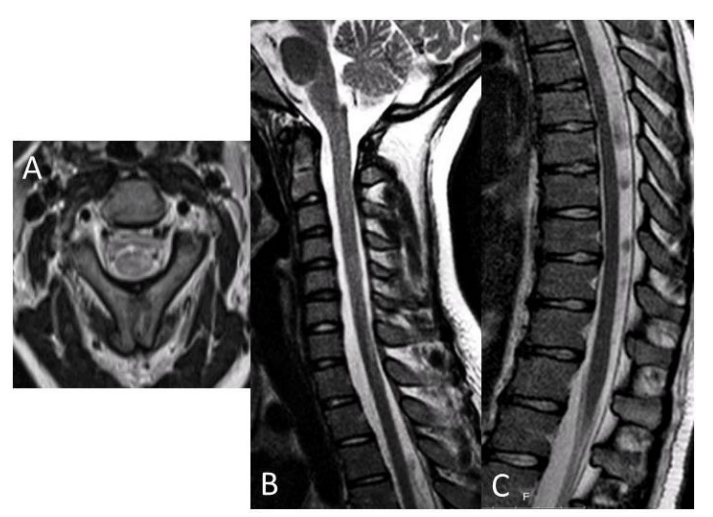

Figure 2 Axial (A) and sagittal (B) T2 image of the cervical spine showing spinal cord lesions. Sagittal (C) T2 image of the dorsolumbar spinal cord showing no lesions in this segment.

\section{Learning points}

- Multiple sclerosis is an immune-mediated disorder of the central nervous system, in which MRI is a key diagnostic tool.

- What we see in image studies does not always match with clinical manifestations and vice versa.

- Although rare, paediatric cases can manifest with extensive and confluent white matter lesions.

in the Expanded Disability Status Scale, due to the presence of brisk reflexes in the lower limbs. Additionally, a new MRI was obtained at this time point, revealing no new lesions.

Despite the exuberant lesions seen on MRI, this patient showed relatively few symptoms, and made a good recovery after corticosteroid treatment. This case highlights the concept of clinical-radiological dissociation, reminding us that imaging findings do not always mirror what we see in the clinical spectrum. Furthermore, it is atypical for paediatric MS patients to show confluent white matter lesions on imaging at the onset of the disease.

Contributors PB and ASE: responsible for conception, scientific research and manuscript writing. FP: responsible for the diagnosis, treatment and follow-up of the patient and reviewer of the article. SC: responsible for reviewing and selecting the images of the patient and reviewer of the article.

Funding The authors have not declared a specific grant for this research from any funding agency in the public, commercial or not-for-profit sectors.

Competing interests None declared.

Patient consent for publication Parental/guardian consent obtained. 
Provenance and peer review Not commissioned; externally peer reviewed.

\section{ORCID iDs}

Pedro Barradas http://orcid.org/0000-0002-1693-5770

Ana Sofia Esteireiro http://orcid.org/0000-0003-1603-0602

\section{REFERENCES}

1 Otallah S, Banwell B. Pediatric multiple sclerosis: an update. Curr Neurol Neurosci Rep 2018; $18: 76$.

Copyright 2020 BMJ Publishing Group. All rights reserved. For permission to reuse any of this content visit https://www.bmj.com/company/products-services/rights-and-licensing/permissions/

BMJ Case Report Fellows may re-use this article for personal use and teaching without any further permission.

Become a Fellow of BMJ Case Reports today and you can:

- Submit as many cases as you like

- Enjoy fast sympathetic peer review and rapid publication of accepted articles

- Access all the published articles

Re-use any of the published material for personal use and teaching without further permission

\section{Customer Service}

If you have any further queries about your subscription, please contact our customer services team on +44 (0) 2071111105 or via email at support@bmj.com.

Visit casereports.bmj.com for more articles like this and to become a Fellow
2 Fadda G, Brown RA, Longoni G, et al. Mri and laboratory features and the performance of international criteria in the diagnosis of multiple sclerosis in children and adolescents: a prospective cohort study. Lancet Child Adolesc Health 2018:2:191-204

3 Banwell B, Arnold DL, Tillema J-M, et al. Mri in the evaluation of pediatric multiple sclerosis. Neurology 2016;87:S88-96. 